\title{
QUALITY OF EDUCATIONAL SERVICES
}

\author{
KVALITETA OBRAZOVNIH USLUGA
}

\author{
Robert Ulewicz \\ Czestochowa University of Technology \\ Czestochowa, Poland/Poljska \\ E-mail: robert.ulewicz@wz.pcz.pl
}

Kanchana Sethanan

Khon Kaen University, Khon Kaen, Thailand/Tajland

\section{Tomasz Nitkiewicz}

Anna Wiśniewska-Sałek

Czestochowa University of Technology

Czestochowa, Poland/Poljska

UDK/UDC: $378.014 .61(438)$

JEL klasifikacija/JEL classification: L15; 23

DOI: $10.30657 /$ hdmk.2020.18

Pregledni članak/Review

Jezik/Language: English/Engleski

\begin{abstract}
The paper presents issues related to the assessment of the quality of education at universities. The paper defines and describes quality determinants from the student's point of view in the aspect of academic staff assessment and course organization. The results of students' research after completing the first year of studies and after choosing an engineering thesis in the aspect of identifying the gap between the expected and actual state of the educational service are presented.
\end{abstract}

Key words: quality, higher education, Kano.

\section{INTRODUCTION}

The educational institution which is a university is one of the most important social institutions. This institution faces difficult tasks and is often criticized for its disappointment or the effects of its work or the way of operation. Universal education is the main development mechanism in the opinion of all those in power, and improving its quality is a priority. Experience shows, however, that many initiatives aimed at increasing the quality of education do not bring the expected results, and instead - consolidate the current state. The contemporary expectations of individual groups of stakeholders are greater than before, and the criticism of the education system is stronger. It is hardly surprising, because the modern world generates previously unknown problems that create a very complicated context for all educational institutions. The complexity of tasks, high quality standards, rate of changes, the desire to 
provide everyone with access to education, rapid changes, the development of science and technology fundamentally affect the situation of universities.

In the literature on the subject you can meet with different categories of university clients. The classification of M. Alvarez and S. Rodríguez ${ }^{1}$ is known, who see the need to focus the attention of university managers not only on the needs of internal clients, such as a university employee or student, but also on external clients, which should be generally understood as society (employers, graduates). In the literature on the subject, special attention is paid to the client, who is the student. ${ }^{2,3}$ For many universities, it is the basic source of income, which is why many universities are taking actions that will make it possible to adjust the educational offer to the constantly changing needs of the student. Such activities usually focus on offering new fields of study - in accordance with the needs of the labour market, enriching the didactic offer with new fields that must be characterized by high flexibility in the choice of material as well as a form of education tailored to the requirements of a modern digital student.

Changes related to the 4.0 transformation as well as the upcoming 5.0 will cause that the implementation pace of new technological and organizational solutions is very large. ${ }^{4,5} \mathrm{On}$ the market of educational services, we are increasingly faced with the situation that the approved study program, in the course of their duration, loses its relevance. Research conducted in the United States indicates that $65 \%$ of students starting education will work in professions that have not yet been defined. The obtained situation is a huge challenge for universities as well as for other stakeholders of the education process.

The question arises how to create a flexible enough education system that will be more adaptive to the changing requirements of the labour market. There are many local, national and international programs aimed at identifying market needs and translating them into an appropriate education program. An example of such a program is the program "Curriculum Development of Master's Degree Program in Industrial Engineering for Thailand Sustainable Smart Industry (MSIE4.0)", which aims to develop a training program adapted to the requirements of Industry 4.0 for industry in Thailand. ${ }^{6}$

\section{DETERMINANTS OF THE QUALITY OF EDUCATION - STUDENTS POINT OF VIEW}

Assessment of the quality of student education is a necessary element inextricably linked to the activities of universities. This is dictated by the need to improve the quality of education resulting from the need to harmonize the Polish higher education system with solutions implemented in the European Higher Education Area. As the literature presents, external and internal system quantifications are used to assess the quality of education in universities. Monitoring of the education process is obligatorily carried out by an external unit.

\footnotetext{
${ }^{1}$ M. Alvarez and S. Rodríguez, La calidad total en la universidad: podemos hablar de clientes?, Boletín de Estudios Económicos, 1997, Vol. LII, 161, pp. 333-352.

${ }^{2}$ Radosław Ryńcza, Zastosowanie wybranych metod i narzędzi w ocenie działalności szkoły wyższej, Oficyna Wydawnicza Politechniki Wrocławskiej, Wrocław, 2014.

3 Richard M. S. Wilson, "Modelling market orientation: an application in the education sector", Journal of Marketing Management, 1998, pp. 14.

4 Michalene Grebski and Wes Grebski, "Project-Based Approach to Engineering Technology Education", Production Engineering Archives, No. 25, 2019, pp. 56-59.

5 Wes Grebski and Michalene Grebski, "Keeping Higher Education Aligned with The Requirements and Expectations of the Knowledge-Based Economy", Production Engineering Archives, No. 21, 2018, pp. 3-7.

${ }^{6}$ Pisut Koomsap, Hussadintorn Na Ayutthaya, Tomasz Nitkiewicz, Rui M. Lima and Huynh Trung Luong, "Course design and development: Focus on student learning experience", International Symposium on Project Approaches in Engineering Education, 2019, 9, pp. 144-153.
} 
Accreditation results indicate, among others, at what level the quality of teaching at universities is shaped.

Internal methods of assessing the quality of education may be different and depend on the nature of the university, the findings of its authorities and the situation determining the demand for the services of the individual. A common method of testing student satisfaction is a survey that adapts directly to the specifics of the individual.

If we approach the quality of educational services at the process level, we can define the components of the areas of entry, operational activities and outputs in the form of an educational service and feedback. Figure 1 shows the system components in process approach.

Figure 1. Process approach to the educational service

\begin{tabular}{|c|c|c|}
\hline $\begin{array}{l}\text { INPUT ELEMENTS } \\
\text { - Human resourcesv } \\
\text { (academic teachers, } \\
\text { administrative staff) } \\
\text { - } \text { Beneficiaries' expectations } \\
\text { - Study programs } \\
\text { - Infrastructure }\end{array}$ & $\begin{array}{l}\text { OPERATIONAL ACTIONS } \\
\text { - providing educational services (work of } \\
\text { teachers, administrative employees, } \\
\text { university management staff, technical } \\
\text { employees, machinery and equipment, } \\
\text { management, administrative, research } \\
\text { and development processes) }\end{array}$ & $\begin{array}{l}\text { OUTPUT ELEMENTS } \\
\text { - } \quad \text { non-material effects } \\
\text { (knowledge, social } \\
\text { competences, skills), } \\
\text { - } \text { material effects (certificates, } \\
\text { diplomas, awards), } \\
\text { - } \quad \text { improvand written information, } \\
\text { improd study programs. }\end{array}$ \\
\hline
\end{tabular}

Source: Own study based on: Wes Grebski and Michalene Grebski, "Keeping Higher Education Aligned with The Requirements and Expectations of the Knowledge-Based Economy”, Production Engineering Archives, No. 21, 2018, pp. 3-7.

An important element in the process of assessing the quality of education is the assessment of the level of student satisfaction.

Figure 2. Areas of evaluation relevant to student satisfaction.

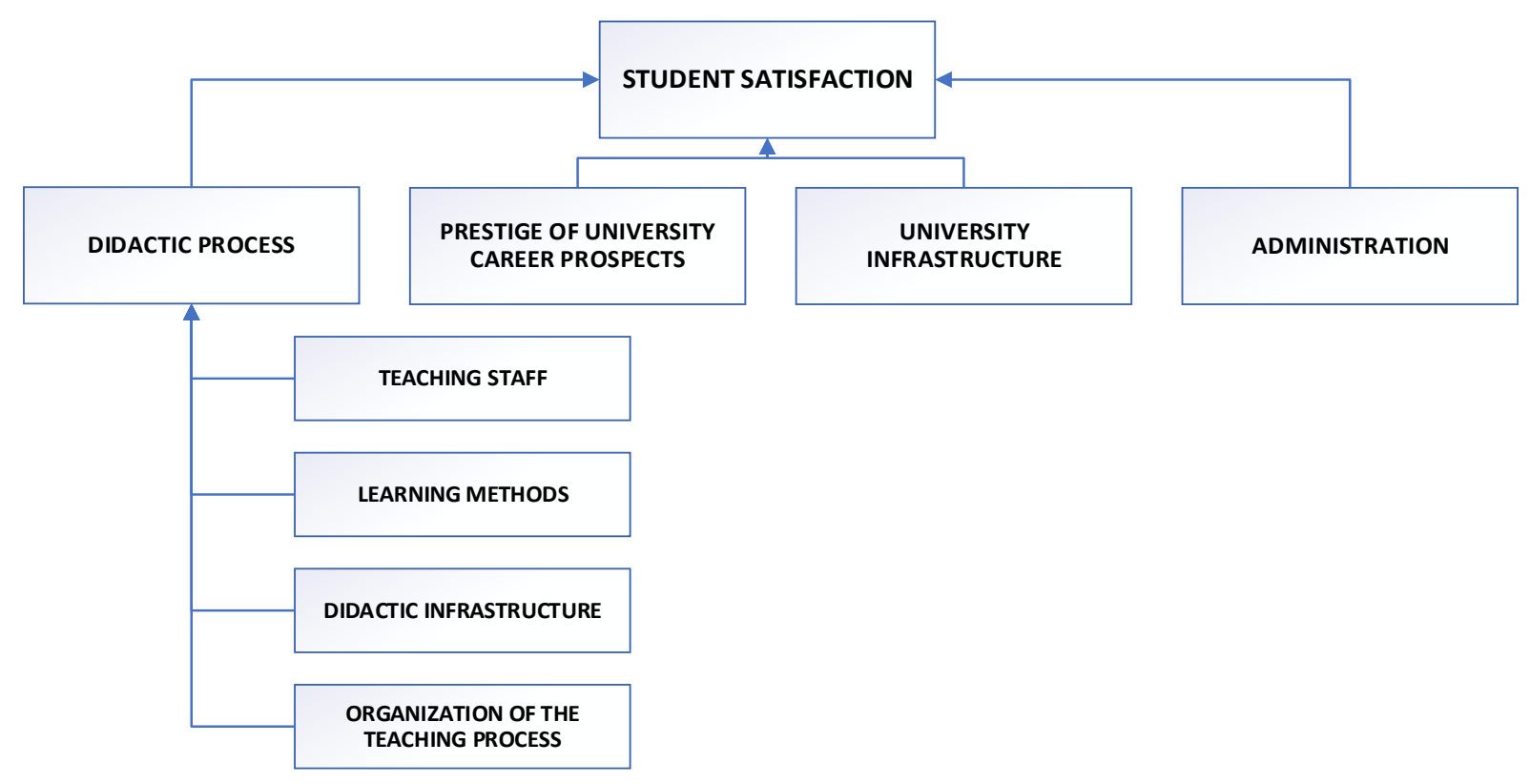


The level of student satisfaction is not only related to the reputation of the university, ${ }^{7}$ but also with the teaching process, administrative support, infrastructure as well as professional perspectives. In his publication, R. Ryńc $z^{8}$ defined relevant areas from the point of view of the student Figure 2. In each of the defined areas, there are a number of factors that are key elements of evaluation from the point of view of student satisfaction. Table 1 presents the determinants of the quality of educational services from the student's point of view.

Table 1. Determinants of the quality of educational services from the point of view of student satisfaction (process approach - elements of entry)

\begin{tabular}{|c|c|}
\hline $\begin{array}{c}\text { Elements of entering the } \\
\text { process }\end{array}$ & Determinants \\
\hline $\begin{array}{l}\text { Human resource (academic } \\
\text { teachers, administrative staff, } \\
\text { university management staff, } \\
\text { technical staff) }\end{array}$ & $\begin{array}{l}\text { Teachers: education, knowledge, teaching experience, ability to } \\
\text { transfer knowledge, communication skills, knowledge of foreign } \\
\text { languages, mobility, the use of the latest multimedia techniques in } \\
\text { conducting classes, interpersonal features affecting good contact with } \\
\text { students and colleagues, } \\
\text { - Administrative employees: knowledge of administrative processes, } \\
\text { experience, communication skills, openness to changes, interpersonal } \\
\text { features affecting good contact with students and colleagues, } \\
\text { - University management staff: knowledge of the area of management of } \\
\text { the educational institution / university, experience, communication } \\
\text { skills, openness to suggestions of students and employees, } \\
\text { Technical employees: knowledge and experience in the field of } \\
\text { performed duties, quick response to reported technical problems; }\end{array}$ \\
\hline $\begin{array}{l}\text { Expectations of beneficiaries } \\
\text { of the educational service - } \\
\text { students (obtaining knowledge } \\
\text { and education ensuring work in } \\
\text { the planned profession, } \\
\text { obtaining a diploma of } \\
\text { completion of a given } \\
\text { educational institution) }\end{array}$ & $\begin{array}{l}\text { Knowledge of the student's own strengths and weaknesses and } \\
\text { educational preferences, } \\
\text { - } \\
\text { - } \quad \text { Opailability of information about a given educational institution, } \\
\text { science festivals allowing future students to get to know the given } \\
\text { institution), } \\
\text { - Scholarship programs and possibilities of obtaining social assistance } \\
\text { for less affluent students, } \\
\text { Educational offer of the educational institution, international contacts } \\
\text { of the university (possibilities of studying abroad), }\end{array}$ \\
\hline Study programs & $\begin{array}{l}\text { - Study programs tailored related of the labour market, } \\
\text { - Flexibility in changing study programs, } \\
\text { - Legal conditions in the field of program content, } \\
\text { - Ministerial guidelines; }\end{array}$ \\
\hline Infrastructure & $\begin{array}{l}\text { - } \quad \text { Condition of the infrastructure, } \\
\text { - The appearance and equipment of the lecture hall, } \\
\text { - Availability of the latest machinery and equipment including laboratory } \\
\text { equipment and lecture rooms }\end{array}$ \\
\hline
\end{tabular}

Source: Own study based on: Radosław Ryńcza, Zastosowanie wybranych metod i narzędzi w ocenie działalności szkoły wyższej, Oficyna Wydawnicza Politechniki Wrocławskiej, Wrocław, 2014.

The basic determinants affecting quality are the human resources of a given university. In particular, staff education, knowledge and experience in the field of teaching, including

\footnotetext{
${ }^{7}$ Deepa Sharma and Ravikala Kamath, Quality in Education. The Quality Circle Way, Kalpaz Publications, Dehli, 2006.

${ }^{8}$ Radosław Ryńcza, Zastosowanie wybranych metod i narzędzi w ocenie działalności szkoły wyższej, Oficyna Wydawnicza Politechniki Wrocławskiej, Wrocław, 2014.
} 
communication skills and a number of interpersonal features enabling good contact between the teacher and students. The digital competences of the teaching staff in the use of modern teaching techniques, working in the cloud, etc. are rated very positively. ${ }^{9}$ Research carried out at the Częstochowa University of Technology as well as literature data indicates the key role of the didactic staff in the aspect of student satisfaction. Currently, students expect not only knowledge from the teaching staff, but above all commitment and problem approach to the presented content (PBL). The results of own research carried out at the Częstochowa University of Technology ${ }^{10}$ as well as research ${ }^{11,12}$ indicate a change in the students' requirements as to the content and form of the transferred knowledge. Students expect a practical - problem approach to the transferred didactic content, and a big plus in the assessment of students is access to digital didactic materials of the subject. Table 2, based on the results of Ryńcz and Kuchta's research and own research, defines the factors of student satisfaction with the teaching staff and organization of the teaching process.

The problem of the evaluation of academic teachers by students is a matter of lively discussion in the academic community. There are no explicit criteria related to the assessment of lecturers by students. At most universities in Poland, students assess the academic staff based on the procedures of the internal quality assurance system of university education. The evaluation process is based on surveys carried out after the course. This is quite a problematic and subjective assessment. Depending on the group in which the research was carried out for the same academic teacher, extremely different grades were obtained.

Table 2. Student satisfaction factors with teaching staff and course organization

\begin{tabular}{|c|c|}
\hline Area & Satisfaction factors \\
\hline Competences and Skills & 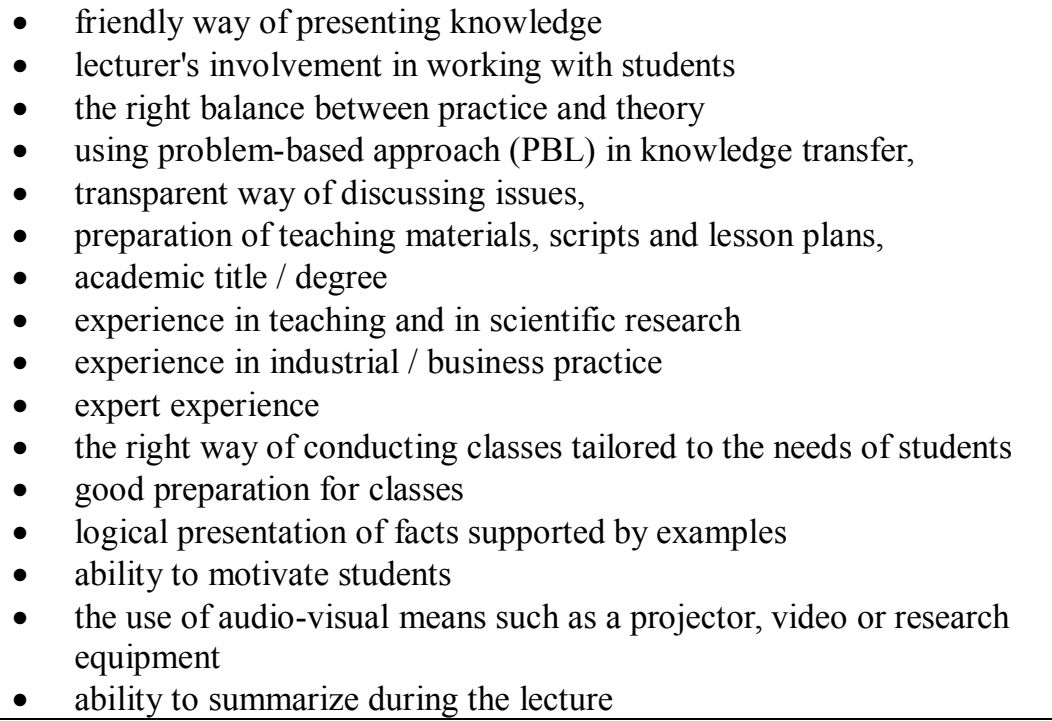 \\
\hline Attitude towards the student & $\begin{array}{l}\text { - } \quad \text { support during studies (technical assistance, etc.) } \\
\text { - level of requirements (e.g. level of difficulty of the course. This factor } \\
\text { may be assessed differently depending on the group of students. Some }\end{array}$ \\
\hline
\end{tabular}

\footnotetext{
${ }^{9}$ B. J. Gray, K.S. Fam and V.A. Llanes, Branding universities in Asia markets, Journal of Product and Brand Management, Vol. 12, No. 2, 2003.

${ }^{10}$ Robert Ulewicz, „Application of servqual method for evaluation of quality of educational services at the university of higher education“, Polish Journal of Management Studies, 2014, 9, pp. 254-264.

11 Radosław Ryńca and Dorota Kuchta, Czynniki satysfakcji studenta, Rachunkowość a controlling, red. E. Nowak, M. Nieplowicz, Zeszyty Naukowe Uniwersytetu Ekonomicznego we Wrocławiu, Wrocław, 2010.

${ }^{12}$ D. K. Banwet and B. Datta, A study of the effect of perceived lecture quality on post-lecture intentions, Work Study, 2003, Vol. 52, No. 5, pp. 234-243.
} 


\begin{tabular}{|c|c|}
\hline & $\begin{array}{l}\text { will appreciate the high level of requirements, while for others the ease } \\
\text { of passing the course will be important) } \\
\text { - discipline during classes (control over a group of students and course of } \\
\text { classes) } \\
\text { - level of difficulty in completing the course } \\
\text { - kindness of the lecturer } \\
\text { - } \quad \text { positive attitude during classes } \\
\text { - lecturer's punctuality } \\
\text { - friendly, tolerant attitude to the student } \\
\text { - fair assessment system } \\
\text { - lecturer's availability, consultation hours, e-mail contact or via instant } \\
\text { - messengers } \\
\text { - the opportunity to discuss outside the classroom, educational platforms, } \\
\text { student forums, } \\
\text { commitment and opportunity to work in science clubs }\end{array}$ \\
\hline Course organization & $\begin{array}{l}\text { - planning didactic classes } \\
\text { - } \\
\text { schedule of activities during the day, week, giving the opportunity to } \\
\text { start work, } \\
\text { - additional breaks during classes }\end{array}$ \\
\hline Course structure & $\begin{array}{l}\text { - } \\
\text { - } \\
\text { appropriate structure of organized courses, e.g. number of lectures, } \\
\text { - } \quad \text { relevance and practical usefulness of course content } \\
\text { - } \quad \text { size of the study group } \\
\text { - } \quad \text { syllabus for students' course developed and available } \\
\text { high availability of lecturers at the university, personal contact as well as } \\
\text { through other communication channels. }\end{array}$ \\
\hline
\end{tabular}

The results of L. Crumbley's research show that in the case of demanding lecturers, students assess such a lecturer in $42 \%$ negative. Negative rating also applies cases of difficult homework assignments and high credit requirements. ${ }^{13}$ L. Langbein ${ }^{14}$ presents similar observations. Based on such data, it is difficult to draw clear conclusions. There is, of course, a verification procedure in the form of class's hospitalization, but most often it is carried out only once a year. Competitions for the best academic teacher or assessing the number of students enrolling in courses for individual teachers are a very good solution. This area of assessing the quality of education is difficult and requires the introduction of new evaluation solutions. Attempts are being made to introduce self-assessment sheets for academic teachers as a complement to the results of the student survey. We do not yet have literature data on the results of introducing such a solution. In the model adopted at the Częstochowa University of Technology giving information on the quality of education and the competence of teaching staff are studies on the level of satisfaction of employers with graduates. However, in this case, the results of the research can also be a very subjective assessment of the situation.

\footnotetext{
${ }^{13}$ L. Crumbley, B. Henry and S. Kratchman, „Students' perceptions of evaluation of college teaching“, Quality Assurance in Education, 2001, Vol. 9, No. 4, pp. 202.

${ }^{14}$ Laura Langbein, Management by results: Student evaluation of faculty teaching and the mismeasurement of performance, Economics of Education Review, 2008, 27(4), 417-428.
} 
Figure 3. Student satisfaction factors

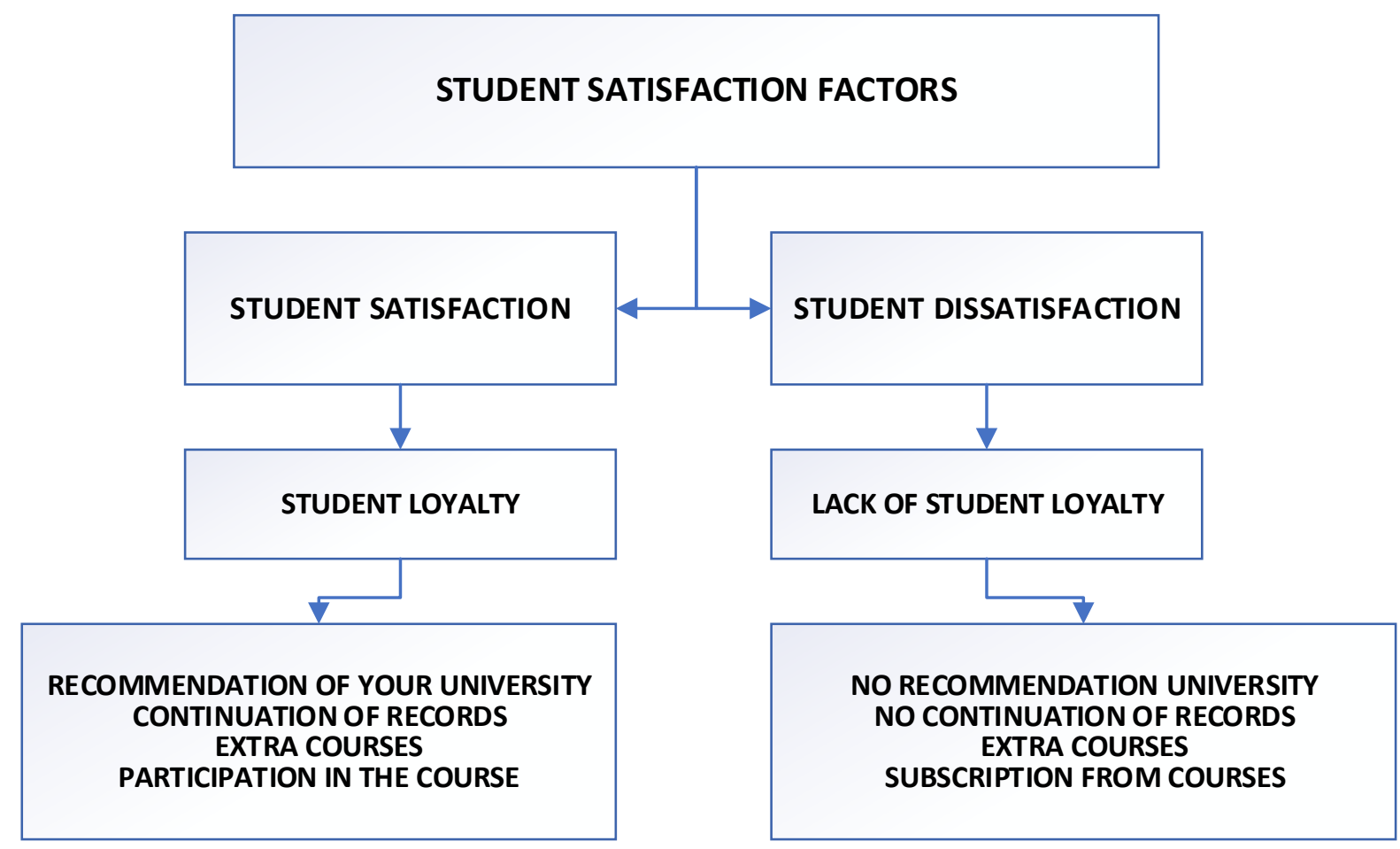

Source: Radosław Ryńcza, Zastosowanie wybranych metod i narzędzi w ocenie działalności szkoły wyższej, Oficyna Wydawnicza Politechniki Wrocławskiej, Wrocław, 2014.

An important factor informing about the quality of the course is student loyalty, in particular in the case of first-cycle studies where students can continue their second-cycle studies at the home university or at another university. Figure 3 presents critical factors of student satisfaction.

\section{RESULTS OF TESTS}

Table 3 and Figure 4 show the partial results of quality assessment education. The research used the KANO method described in. ${ }^{15,16,17}$ The research results concern the assessment of the quality of education from the point of view of students. The research results for the same group of students were presented after completing the first year of studies and after defending engineering thesis. After completing the first year, students identified the ten most important in their opinion features that were included in further studies:

1. Theoretical knowledge possessed;

2. Practical knowledge possessed;

\footnotetext{
${ }^{15}$ Mahboube Arefi, Mahmood Heidari, Gholamreza Shams Morkani and Khalil Zandi, Application of Kano Model in Higher Education Quality Improvement: Study Master's Degree Program of Educational Psychology in State Universities of Tehran, World Applied Sciences Journal, 17 (3), 2012.

${ }^{16}$ Md. Mamunur Rashid, Jun'ichi Tamaki, A. M. M. Sharif Ullah., Akihiko Kubo, „A Kano Model Based Linguistic Application for Customer Needs Analysis“, International Journal of Engineering Business Management, 3(2), 2011.

${ }^{17}$ Manuela Ingaldi and Robert Ulewicz, „How to Make E-Commerce More Successful by Use of Kano's Model to Assess Customer Satisfaction in Terms of Sustainable Development“, Sustainability, 11, 2019, pp. 4830.
} 
3. The right balance between theoretical and practical knowledge;

4. A transparent way of discussing issues;

5. Logical presentation of facts supported by examples;

6. Applying a problem approach in transferring knowledge;

7. Timeliness of course content / material selection;

8. Lecturer's communication skills and availability;

9. Ability to motivate students;

10. Discipline during classes (control over a group of students and course of classes).

Features that should necessarily be $(\mathrm{M})$ provided in the implementation of the service are those marked with numbers: 1, 5, and 8, attractive (A) 2, 4, 6, 7, 9, 10 indifferent and doubtful features were not indicated. After defending students' engineering thesis, they were again asked to define the features. Features 1, 2, 3, 5, 6, 7 were defined as necessary (M) and features 4, 8, 9, 10 as attractive (A), indifferent and doubtful features were not indicated.

Table 3. Quality of education from the student's point of view

\begin{tabular}{|c|c|c|c|c|}
\hline Feature & Weight & Rating & Expectancy & Gap \\
\hline \multicolumn{5}{|c|}{ students after the first year of study } \\
\hline 1.M & 2.7 & 5.5 & 7.0 & -1.5 \\
\hline 2.A & 2.0 & 3.5 & 6.4 & -2.9 \\
\hline 3.A & 1.2 & 4.1 & 5.2 & -1.1 \\
\hline $4 . \mathrm{A}$ & 2.1 & 4.2 & 4.9 & -0.7 \\
\hline 5.M & 1.5 & 3.9 & 4.1 & -0.2 \\
\hline 6.A & 1.3 & 2.1 & 3.8 & -1.6 \\
\hline 7.A & 1.4 & 3.6 & 4.3 & -0.7 \\
\hline 8.M & 1.9 & 3.1 & 6.8 & -3.7 \\
\hline 9.A & 1.2 & 3.2 & 3.8 & -0.6 \\
\hline 10.A & 1.4 & 3.7 & 2.6 & 1.2 \\
\hline \multicolumn{5}{|c|}{ students after defending their engineering thesis } \\
\hline $1 . \mathrm{M}$ & 2.6 & 5.4 & 7.0 & -1.6 \\
\hline 2.M & 2.8 & 5.8 & 7.0 & -1.2 \\
\hline 3.M & 2.0 & 4.1 & 5.2 & -1.1 \\
\hline 4.A & 2.1 & 5.2 & 4.9 & 0.3 \\
\hline $5 . \mathrm{M}$ & 2.0 & 3.9 & 4.1 & -0.2 \\
\hline $6 . \mathrm{M}$ & 2.1 & 4.2 & 6.2 & -2.0 \\
\hline 7.M & 2.2 & 3.6 & 4.3 & -0.7 \\
\hline $8 . \mathrm{A}$ & 1.9 & 4.5 & 6.8 & -2.3 \\
\hline 9.A & 2.1 & 4.1 & 3.8 & 0.4 \\
\hline 10.A & 1.3 & 3.6 & 2.6 & 1.1 \\
\hline
\end{tabular}

The perspective of quality perception changes with the time spent studying. As can be seen from the data in Table 3 and Fig. 4, as the student experience increases, the requirements for practical knowledge and problem learning increase significantly. 
Figure 4. Quality of education from the student's point of view:

a) students after the first year of study,

b) students after defending their engineering thesis

a)

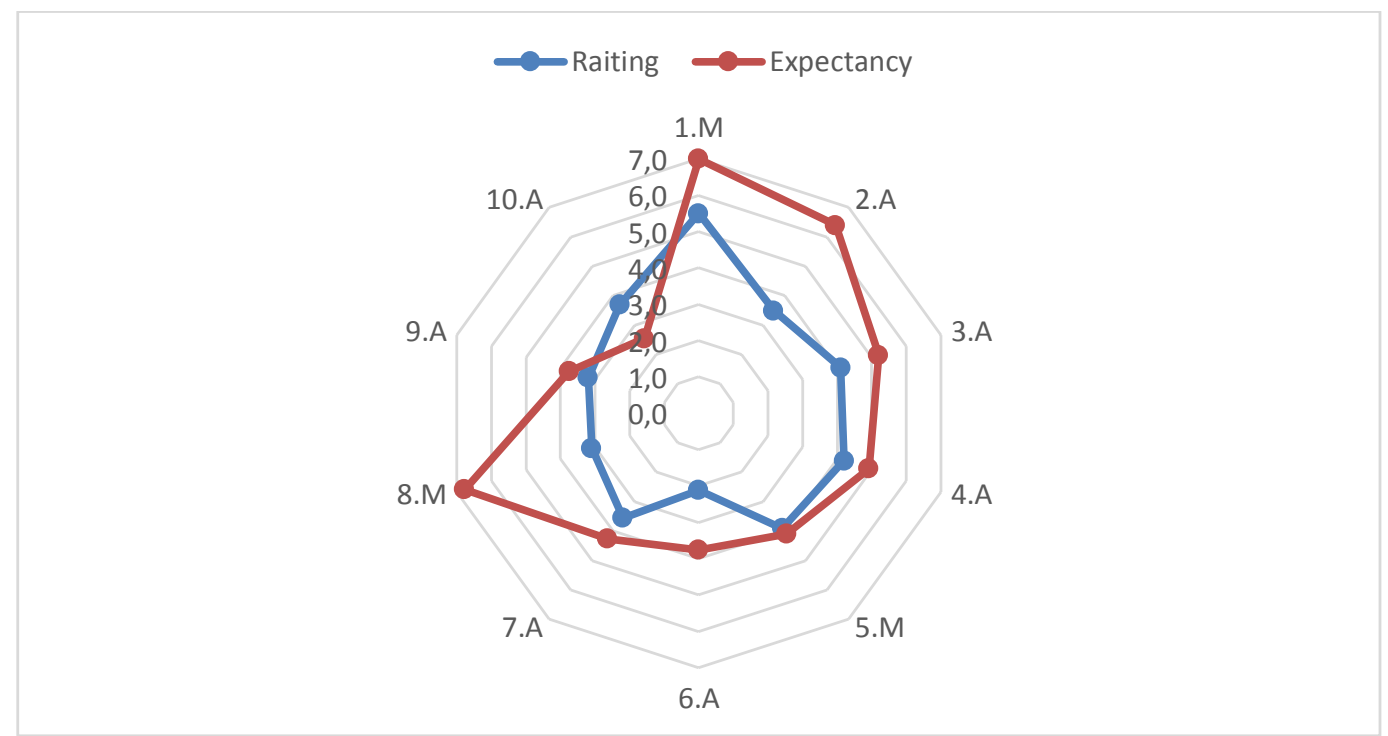

b)

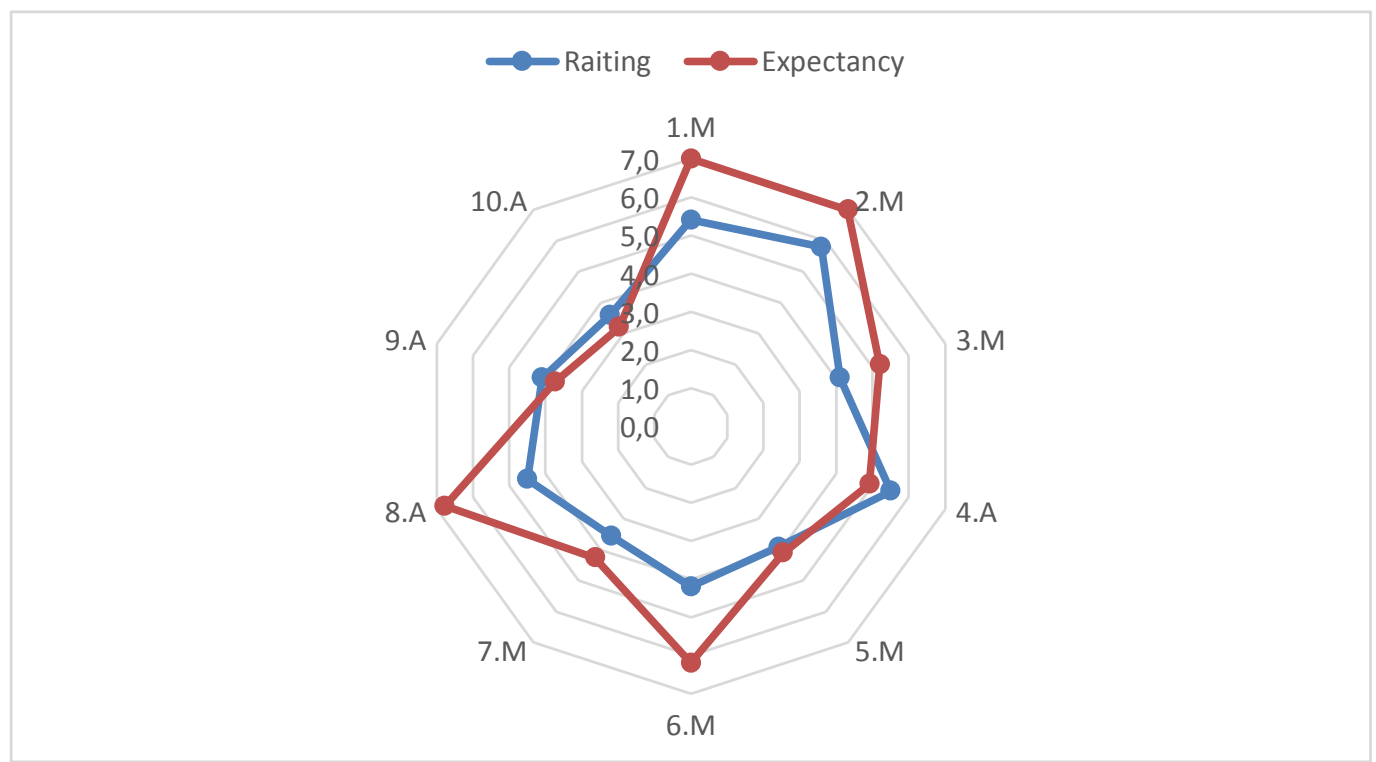

The factor of practical knowledge changed from attractive to require as well as in the case of problem-based teaching.

\section{CONLUSION}

In the conditions of growing competition on the market of educational services, an organization that does not want to lose its current strong position on the market must adapt its teaching offer to the current, but anticipated future needs of its clients. As research shows, the requirements of stakeholders in the teaching process as well as the timeliness of the content being taught are changing. The results of KANO's research indicate an increasingly important role of the practical and problem approach in the scope of the didactic process implementation 
as well as the timeliness of program content. These factors are of great importance in terms of loyalty of first-degree students towards the university and the desire to continue their education in second-cycle studies. We are dealing more and more often with a conscious student who uses his acquired knowledge at work during his studies. He is increasingly looking for opportunities to solve practical problems at university. This is a great challenge not only for academic teachers themselves but also for those who create study programs. We also need support for academic staff in the use of new teaching methods, e.g. PBL.

\section{ACKNOWLEDGEMENTS}

This publication is under the project "Curriculum Development of Master's Degree Program in Industrial Engineering for Thailand Sustainable Smart Industry (MSIE4.0)" that has been funded with support from the European Commission (Project

Number: 586137-EPP-1-2017-1-TH-EPPKA2-CBHE-JP).

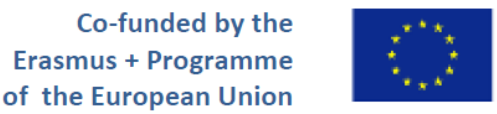

\section{Sažetak:}

\section{KVALITETA OBRAZOVNIH USLUGA}

U radu su predstavljena pitanja vezana uz ocjenu kvalitete obrazovanja na sveučilištima. U radu su definirane i opisane odrednice kvalitete sa stanovišta studenta s aspekta procjene akademskog osoblja $i$ organizacije kolegija. Predstavljeni su rezultati istraživanja studenata nakon završene prve godine studija i nakon odabira inženjerskog završnog rada s aspekta utvrđivanja jaza između očekivanog $i$ stvarnog stvarnog ishoda učenja.

Ključne riječi: kvaliteta, visoko obrazovanje, Kano.

\section{LITERATURE}

1. Arefi M., Heidari M., Shams Morkani G. and K. Zandi, "Application of Kano Model in Higher Education Quality Improvement: Study Master's Degree Program of Educational Psychology in State Universities of Tehran", World Applied Sciences Journal, Vol. 17, No. 3, 2012.

2. Alvarez, M. and S. Rodríguez, La calidad total en la universidad: podemos hablar de clientes?, Boletín de Estudios Económicos, , Vol. LII, 161, 1997.

3. Banwet, D.K. and B. Datta, A study of the effect of perceived lecture quality on post-lecture intentions, Work Study, Vol. 52, No. 5, 2003.

4. Crumbley, L., Henry, B. and S. Kratchman, Students' perceptions of evaluation of college teaching, Quality Assurance in Education, Vol. 9, No. 4, 2001.

5. Gray, B. J., Fam, K.S. and V. A. Llanes, "Branding universities in Asia markets", Journal of Product and Brand Management, Vol. 12, No. 2, 2003.

6. Grebski, M. and W. Grebski, "Project-Based Approach to Engineering Technology Education" Production Engineering Archives, 25, 2019.

7. Grebski, W. and M. Grebski, "Keeping Higher Education Aligned with the Requirements and Expectations of the Knowledge-Based Economy", Production Engineering Archives $21,2018$.

8. Ingaldi, M. and R. Ulewicz, "How to Make E-Commerce More Successful by Use of Kano's Model to Assess Customer Satisfaction in Terms of Sustainable Development", Sustainability 11, 2019. 
9. Koomsap, P., Na Ayutthaya, D. H., Nitkiewicz, T., Lima, R.M. and H. T. Luong, Course design and development: Focus on student learning experience, International Symposium on Project Approaches in Engineering Education, 9, 2019.

10. Langbein, L., "Management by results: Student evaluation of faculty teaching and the mismeasurement of performance", Economics of Education Review, Vol. 27, No. 4, 2008.

11. Rashid, M. M., Tamaki, J., Ullah., A.M.M.S. and A. Kubo, “A Kano Model Based Linguistic Application for Customer Needs Analysis", International Journal of Engineering Business Management, No. 3, Vol. 2, 2011.

12. Ryńca, R. And D. Kuchta, Czynniki satysfakcji studenta, Rachunkowość a controlling, red. E. Nowak, M. Nieplowicz, Zeszyty Naukowe Uniwersytetu Ekonomicznego we Wrocławiu, Wrocław, 2010.

13. Ryńcza, R., Zastosowanie wybranych metod i narzędzi w ocenie działalności szkoły wyższej, Oficyna Wydawnicza Politechniki Wrocławskiej, Wrocław, 2014.

14. Sallis, E., Total Quality Management in Education, Kogan Page, London 1993; N.Y.M. Siu,

15. Sharma, D. and R. Kamath, Quality in Education. The Quality Circle Way, Kalpaz Publications, Dehli, 2006.

16. Ulewicz, R., "Application of servqual method for evaluation of quality of educational services at the university of higher education", Polish Journal of Management Studies, 9, 2014.

17. Wilson, R.M.S., "Modelling market orientation: an application in the education sector", Journal of Marketing Management, 14, 1998. 